\title{
Perception and its Impact on Satisfaction on Performance Appraisal in Real Estate Industry in South India
}

\author{
R. Sridhar ${ }^{1}$ and N. Elangovan ${ }^{2}$ \\ ${ }^{1}$ Research Scholar, Department of Management Studies, Christ University, Karnataka, India \& \\ Vice President, Human Resources, Shriram Properties, Bangalore, Karnataka, India \\ ${ }^{2}$ Director, National Institute of Fashion Technology, Kannur, Kerala, India \\ E-Mail: jandjdas@gmail.com, elaengovan@gmail.com
}

\begin{abstract}
Traditionally, real estate industry is managed by small time entrepreneurs and considered as unorganized industry. However, in the last few decades, the real estate industry has become organized sector with many corporate houses started doing business and offering employment to millions. Like any other organized industry, Real estate industry too started practicing performance appraisal to reward their employees and to align their goal with the organization. The nature of the business allows the organizations in Real Estate industry to have diversified work groups. Thus, organization's role on implementing better performance appraisal system becomes inevitable. This study aims at identifying the perception of the real estate employees on performance appraisal system, organizational role in educating the employee on performance appraisal system and their impact on the satisfaction of the employee on the performance appraisal system practiced in Real Estate companies
\end{abstract}

Keywords: Perception, Performance Appraisal, Real Estate

\section{INTRODUCTION}

There are unlimited number of research has been done in the study of performance appraisal. Although there are studies available on perception on performance appraisal, there are limited study has been done in perception on performance appraisal and its impact on satisfaction on performance appraisal in the real estate industry. Real Estate industry is tradionatilly an unorganized industry in India.

In recent times, lot of corporate houses has entered Real Estate business. From local market to national level, these corporate houses started establishing the real estate business. Result of this, this industry has become the one of the largest job providing industry.

The purpose of this qualitative study is to investigate the awareness on performance appraisal process in Real Estate industry in South India, the relationship between the perception on the performance appraisal and the satisfaction of the employee on performance appraisal.

This study does not measure whether the performance appraisal is conducted accurately or not. This study does not consider the various biases identified by the various researcher in the study of performance appraisal.

\section{A. Need for the Study}

Employees opinion on the fairness of performance appraisal is key parameter in measuring the various outcome of organizational growth, its commitment to the career development of the employee. These parameters are directly connected to satisfaction of the employee on performance appraisal. justification is recommended. Implementation of Performance Appraisal systems remains one of the greatest challenges of effective HRM (Taylor et al., 1995). Employee expects the better Performance Appraisal System so that it gives the valuable feedback about the performance of the employee. Every individual is eager to know the progress he or she made in the work during the appraised period. Every employee is eager to know whether he or she is aligned with the progress of the organization. Perceptions of Performance Appraisal system can lead to satisfaction with Performance Appraisal system (Cawley et al., 1998; Jawahar, 2007; Thurston and McNall, 2010).

\section{B. Objectives of the Study}

To explore the relationship between the perception on performance appraisal and its impact on satisfaction on performance appraisal in Real Estate Industry in South India.

\section{Scope of this Study}

The study is confined to employees working in a Real Estate companies in South India. This study does not include construction or blue collar workers. This study includes employees working in corporate Real Estate companies. For the purpose of this study, two large Real Estate companies are considered.

\section{Hypothesis}

$H_{1}$ : There is no significant impact of Perception on Performance Appraisal on Satisfaction on Performance Appraisal in Real Estate in South India.

$\mathrm{H}_{2}$ : There is no significant difference between employee experience (in years) and the perception on performance appraisal in Real Esate in South India. 


\section{LITERATURE REVIEW}

\section{A. Perception on Performance Appraisal}

An employee may have the opinion on performance appraisal based on his perception and outcome of the appraisal process. When employees perceive the process to be fair, they are more likely to conclude that they are valued by the organization, which may then increase the likelihood of employees engaging in behaviors that are beneficial to the organization (De Cremer et al., 2010). Subordinates have been shown to react more positively towards an appraisal system if they are involved in the appraisal's construction (Thurston \& McNall, 2010); Ssubordinates' evaluations of the appeals process associated with an appraisal affected their job satisfaction (Shrivastava \& Purang, 2011; Thurston \& McNall, 2010). Reactions to appraisal and the appraisal process are believed to significantly influence the effectiveness and the overall viability of appraisal systems ( Jawahar, 2007).

\section{B. Satisfaction on Performance Appraisal}

Bretz, Milkovich and Read (1992) indicate that the most important performance appraisal issue faced by organizations is the perceived fairness of the performance review and the performance appraisal system. Their findings suggested that most employees perceive their performance appraisal system as neither accurate nor fair.

Skarlicki and Folger (1997) suggest that the appraisal process can become a source of extreme dissatisfaction when employees believe the system is biased, political, or irrelevant. Perceptions of fairness arise from consideration of the outcomes received (outcome fairness); the procedures used to determine those outcomes (procedural fairness); and the way in which the decision-making procedures were implemented and explained (interpersonal fairness) (Smither, 1998). Landy and Farr (1980) generalized that a fair evaluation is one that contains certain procedural elements regardless of the outcomes of the evaluations themselves.

The literature reviews provided literature evidences for the impact of perception on performance appraisal on Satisfaction performance appraisal. While large number of study has been done on perception on performance appraisal and satisfaction on job, there are very relatively very few study has been done on the relationship between perception on performance appraisal and satisfaction on performance appraisal especially in Real Estate Industry in South Indian context.

\section{METHODOLOGY}

The study follows descriptive research design. The population for the study is employees working in Real Estate companies but limited to non-construction workers. Participants included men and women working in Real
Estate companies in South India. Participants who were currently working but not undergone performance appraisal were excluded. To access this population, HR managers in different companies were contacted over phone and email. The sampling frame for this study was one month and the total number of eligible Reponses was 386. The survey was distributed through WhatsApp messages, Posting in LinkedIn professional social media and Zoho, online survey platform.

A questionnaire consisting of measures of Perception on Performance Appraisal and Satisfaction on Performance Appraisal was developed. The measure was based on the mean score of the associated questionnaire items. A response of " 1 " on a Likert-type scale, indicated the lowest degree of perception on Performance Appraisal and "5" indicated the highest degree of Perception on Performance Appraisal. The questionnaire items measuring the Perception on Performance Appraisal were adapted from the research of Panggabean, M. S. (2001). The overall mean of the 6 items measuring perception on performance appraisal is 4.19 with variance of 0.6 and Cronbach's alpha was 0.708 .

The dependent variable in this survey is satisfaction on performance appraisal system. The measure was based on the mean score of the associated questionnaire items. A response of " 1 " on a Likert-type scale, indicated the lowest degree of satisfaction and " 5 " indicated the highest degree of satisfaction. Several of the questionnaire items measuring the satisfaction performance appraisal were adapted from the research of Murphy, K. R (1986), Walsh, M. B (2003) and Aly, N. A. E. F. M., \& El-Shanawany, S. M. (2016). The overall mean of the 7 items measuring Satisfaction on performance appraisal is 3.8 with variance of 0.632 and Cronbach's alpha was 0.876 .

\section{FINDINGS AND DISCUSSIONS}

TABLE I DistribUtion OF POPULATION BASED ON EDUCATION QUALIFICATION, NUMBER OF TIMES UNDERGONE PERFORMANCE APPRAISAL

\begin{tabular}{|c|c|c|c|}
\hline Classification & Category & $\begin{array}{l}\text { Number of } \\
\text { Individuals }\end{array}$ & $\begin{array}{c}\text { Populations } \\
\text { Site } \\
\end{array}$ \\
\hline \multirow{5}{*}{$\begin{array}{l}\text { Number of } \\
\text { times } \\
\text { employee } \\
\text { undergone } \\
\text { Performance } \\
\text { Appraisal }\end{array}$} & One time & 47 & \multirow{5}{*}{386} \\
\hline & Two Times & 87 & \\
\hline & Three Times & 127 & \\
\hline & Four Times & 72 & \\
\hline & Five Times & 53 & \\
\hline \multirow{6}{*}{ Education } & Diploma & 5 & \multirow{6}{*}{386} \\
\hline & PUC & 5 & \\
\hline & Degree & 110 & \\
\hline & $\begin{array}{l}\text { Post } \\
\text { Graduate }\end{array}$ & 190 & \\
\hline & $\begin{array}{l}\text { Professional } \\
\text { Degree }\end{array}$ & 71 & \\
\hline & $\begin{array}{l}\text { Other } \\
\text { Degrees }\end{array}$ & 5 & \\
\hline
\end{tabular}


Simple linear Regression analysis was applied to test the model and t-test was applied to test the hypothesis.

The responses collected through the survey was analysed using statistical toll SPSS. The results have confirmed a significant relationship between perception on performance appraisal and satisfaction on performance appraisal and both alternative hypothesis were accepted.
Table I Distribution of population based on Education qualification, Number of times undergone Performance Appraisal.

Out of 386 respondents majority were (65.2\%) were apprised more than 3 times and majority of the respondents (96.11\%) were completed degree and above.

TABLE Ii PERCEPtion Of RATING ON DifFERENT Dimensions

\begin{tabular}{|c|c|c|c|c|c|c|c|c|c|c|}
\hline \multirow{2}{*}{ Dimension } & \multicolumn{2}{|c|}{$\begin{array}{l}\text { Strongly } \\
\text { Disagree }\end{array}$} & \multicolumn{2}{|c|}{$\begin{array}{l}\text { Strongly } \\
\text { Disagree }\end{array}$} & \multicolumn{2}{|c|}{ Neutral } & \multicolumn{2}{|c|}{$\begin{array}{c}\text { Strongly } \\
\text { Agree }\end{array}$} & \multicolumn{2}{|c|}{$\begin{array}{c}\text { Strongly } \\
\text { Agree }\end{array}$} \\
\hline & No. & $\%$ & No. & $\%$ & No. & $\%$ & No. & $\%$ & No. & $\%$ \\
\hline Satisfied with rating & 45 & $12 \%$ & 93 & $24 \%$ & 132 & $34 \%$ & 74 & $19 \%$ & 42 & $11 \%$ \\
\hline Accurate rating & 40 & $10 \%$ & 102 & $26 \%$ & 132 & $34 \%$ & 75 & $19 \%$ & 37 & $10 \%$ \\
\hline Satisfied with Process & 56 & $15 \%$ & 126 & $33 \%$ & 80 & $21 \%$ & 83 & $22 \%$ & 41 & $11 \%$ \\
\hline Satisfied with feedback & 46 & $12 \%$ & 101 & $26 \%$ & 87 & $23 \%$ & 120 & $31 \%$ & 32 & $8 \%$ \\
\hline Feedback covered the actual work & 56 & $15 \%$ & 87 & $23 \%$ & 108 & $28 \%$ & 103 & $27 \%$ & 32 & $8 \%$ \\
\hline Unbiased rating & 71 & $18 \%$ & 55 & $14 \%$ & 109 & $28 \%$ & 83 & $22 \%$ & 68 & $18 \%$ \\
\hline Expectations met & 45 & $12 \%$ & 103 & $27 \%$ & 135 & $35 \%$ & 60 & $16 \%$ & 43 & $11 \%$ \\
\hline
\end{tabular}

The Table II reveals that $36 \%$ of the employees are not satisfied with the rating they have received and 34\% of the employees are neither satisfied nor unhappy. This is validated by a parameter on accurate rating. 36\% of the employees feel that they are not rated properly and 34\% of the employees are not able to derive on a opinion about accurate rating. While $47 \%$ of the employees are not happy with the process and $21 \%$ of the employees are not able to validate the process. The trend is similar for a parameter on satisfaction on the feedback. 38\% are not satisfied with the feed back and 23\% are not able comment. Over all, 73\% of the employees feel that their expectations were not met by the appraisal process.

TABLE III Simple LineAR REgRession OF THE PREDICTOR OR RESPONSE VARIABLE

\begin{tabular}{|c|c|c|c|c|}
\hline Model & R & $\begin{array}{c}\text { R } \\
\text { Square }\end{array}$ & $\begin{array}{c}\text { Adjusted R } \\
\text { Square }\end{array}$ & $\begin{array}{c}\text { Std. Error of } \\
\text { the Estimate }\end{array}$ \\
\hline 1 & $.678^{\mathrm{a}}$ & .460 & .451 & .69911 \\
\hline \multicolumn{4}{|c|}{ a. Predictors: (Constant), PerOnPA } \\
\hline
\end{tabular}

TABLE IV GoOdness Of FIT Of THE Model

\begin{tabular}{|c|c|c|c|c|c|c|}
\hline \multicolumn{7}{|c|}{ ANOVA $^{\text {a }}$} \\
\hline \multirow{2}{*}{ Model } & $\begin{array}{c}\text { Sum of } \\
\text { Squares }\end{array}$ & Df & $\begin{array}{c}\text { Mean } \\
\text { Square }\end{array}$ & F & Sig. \\
\hline \multirow{2}{*}{1} & Regression & 157.756 & 6 & 26.293 & 53.795 & $.000^{\mathrm{b}}$ \\
\cline { 2 - 7 } & Residual & 185.239 & 379 & .489 & & \\
\cline { 2 - 7 } & Total & 342.995 & 385 & & & \\
\hline \multicolumn{7}{|c|}{ a. Dependent Variable: SatOnPA } \\
\hline \multicolumn{7}{|c|}{ b. Predictors: (Constant), PerOnPA } \\
\hline
\end{tabular}

Table III Simple linear regression shows that overall $46 \%$ of the variation in the dependent variable is explained by the regression model. We are predicting the scores on Satisfaction from the scores on a Perception. The result obtained confirms the positive relationship between perception on performance appraisal and employee's satisfaction on performance appraisal.

Table IV explains a goodness of fit test explains how well the independent variable Perception of Performance Appraisal fits significantly with the dependent variable Satisfaction on performance appraisal. The table IV explains about the goodness of the model fit and significance value is $\mathrm{p}<.01$ it is evident the model is fitted well. Hence the alternative hypothesis is accepted that there is a significant impact of Perception on Satisfaction in performance appraisal process in Real Estate companies.

TABle V Significance Of The Predictor Over Response VARiable

\begin{tabular}{|c|c|c|c|c|c|c|}
\hline \multicolumn{7}{|c|}{ Coefficients $^{\text {a }}$} \\
\hline \multirow{2}{*}{ Model } & $\begin{array}{c}\text { Unstandardized } \\
\text { Coefficients }\end{array}$ & $\begin{array}{c}\text { Standardized } \\
\text { Coefficients }\end{array}$ & \multirow{2}{*}{ t } & Sig. \\
\cline { 2 - 5 } & B & $\begin{array}{c}\text { Std. } \\
\text { Error }\end{array}$ & Beta & & \\
\hline \multirow{2}{*}{1} & $\begin{array}{c}\text { Per } \\
\text { OnPA }\end{array}$ & .160 & .052 & .120 & \multirow{2}{*}{3.086} & .002 \\
\hline \multicolumn{7}{|c|}{ a. Dependent Variable: SatOnPA } \\
\hline
\end{tabular}

Table V says The independent variable Perception Performance Appraisal shows significant relationship with the dependent variable Satisfaction on Performance Appraisal $(\mathrm{p}<.05)$.

The data presented in this study reveals that the employees do not have clarity on performance appraisal and they are not satisfied with the Performance Appraisal process in their organization. The employees participated in the survey 
clearly agreed that every one must be trained in performance management techniques. Also, the participants have agreed that performance appraisal should be the integral part of the relationship between the employee and the line manager. It is clearly revealed that employees feel the current performance appraisal process is merely an administrative process.

\section{CONCLUSION}

Research findings have supported that South Indian Real Estate Corporate companies have performance appraisal system which require better evaluation and feedback methods and create awareness among the employees about the process. Real Estate companies should conduct the training programs or awareness session to conduct the performance appraisal system effectively. Employees will be more knowledgeable if proper introduction on performance appraisal process is given to them. Such an awareness will increase the positive perception on performance appraisal and help employees to either strongly agree with the process and feedback mechanism or strongly disagree the process and feedback mechanism.

\section{REFERENCES}

[1] Aly, N. A. E. F. M., \& El-Shanawany, S. M. (2016). The Influence of Performance Appraisal Satisfaction on Nurses' Motivation and Their Work Outcomes in Critical Care and Toxicology Units. European Scientific Journal, ESJ, 12(20).

[2] Bretz, R. D., Milkovich, G. T. and Read, W. (1992). The Current State of Performance Appraisal Research and Practice: Concerns, Directions and Implications, Centre for Advanced Human Resource Studies.
[3] Cawley, B. D., Keeping, L. M. and Levy, P. E. (1998). Participation in the performance appraisal process and employee reactions: a metaanalytic review of field investigations. Journal of Applied Psychology, 83(4), 615-33.

[4] De Cremer, D., Brockner, J., Fishman, A., Van Dijke, M., van Olffen, W., \& Mayer, D. M. (2010). When do procedural fairness and outcome fairness interact to influence employees' work attitudes and behaviors? The moderating effect of uncertainty. Journal of Applied Psychology, 95(2), 291-304.Deprez-Sims.

[5] Jawahar, I. M. (2007). The influence of perceptions of fairness on performance appraisal reactions, Journal of Labour Research, 28(4), 735-54.

[6] Landy, F. J., \& Farr, J. L. (1980). Performance rating. Psychological Bulletin, 87(1), 72.

[7] Murphy, K.R. and Cleveland, J.N., (1995), Understanding performance appraisal: social, organizational and goal-based perspectives. Sage, Thousand Oaks, CA

[8] Panggabean, M. S. (2001). Performance Appraisal. Manajemen Krida Wacana, 1(2).

[9] Skarlicki D P and Folger R (1997), Retaliation in the Workplace: The Roles of Distributive, Procedural and Interactional Justice, Journal of Applied Psychology, 82, 434-443

[10] Smither, J. W. (Ed.). (1998). Performance appraisal: State of the art in practice. Pfeiffer.

[11] Shrivastava, A. A., \& Purang, P. P. (2011). Employee perceptions of performance appraisals: A comparative study on Indian banks. The International Journal of Human Resource Management, 22(3), 632647.

[12] Taylor, M.S., Tracy, K.B., Harrison, J.K. and Carroll, S.J. (1995), Due process in performance appraisal: a quasi-experiment in procedural justice, Administrative Science Quarterly, 40(3), 495-523

[13] Thurston Jr., P. W., \& McNall, L. (2010). Justice perceptions of performance appraisal practices. Journal of Managerial Psychology, 25(3), 201-228. Weiss,

[14] Walsh, M. B. (2003). Perceived fairness of and satisfaction with employee performance appraisal. 